\title{
I JURAGAN ANOM: (SEBUAH KAJIAN TEKSTUAL)
}

\author{
Ida Bagus Putra Yadnya ${ }^{2}$ \\ Universitas Udayana \\ putrayadnya@yahoo.com
}

\begin{abstract}
ABSTRAK
Tulisan ini ditujukan untuk memberikan tinjauan teoretis mengenai konsep konteks situasi dan aplikasi model teoretis Hallday (1985) tentang konteks situasi terhadap teks I Juragan Anom, sebuah teks tradisional Bali berwujud prosa naratif yang tidak saja bisa dipahami sebagai suatu cerita rakyat yang bercerita tentang perjalanan hidup karakter di dalam cerita tersebut yang dikemas dalam struktur kisahan cerita Panji dan memiliki sejumlah kesamaan struktur alur universal dari the Hero of Tradition serta memiliki bobot edukatif bagi pendidikan dan pembinaan anak-anak. Jangkauan pembicaraan dan kajian terhadap teks tersebut terbatas pada (1) kesatuan teks yang mencakup kesatuan struktur dan texture, (2) konteks situasi dan (3) konteks budayanya.
\end{abstract}

Kata kunci: konteks situasi, konteks budaya

\section{ABSTRACT}

This article is intended to provide a theoretical review of the concept of the context of situation and the application of theoretical models of Hallday (1985) to I Juragan Anom, a Balinese traditional text in the form of prose narrative that can be understood as a folklore telling about the life journey of character that is packaged in Panji narrative structure that has a number of similarities with the universal structure of " the Hero of Tradition". The scope of discussion is limited to (1) the unity of the text that includes the unity of structure and texture, (2) the context of situation and (3) cultural context.

\section{PENDAHULUAN}

Bahasa adalah instrumen utama manusia dalam mengintegrasikan dirinya baik secara internal maupun eksternal sebagai individu yang berfungsi dan partisipan aktif dalam kelompok atau masyarakat (Mc Quown, 1978:171) Oleh karenanya kajian tentang bahasa harus selalu menempatkan kajian itu dalam hubungannya dengan kehidupan manuasia (Harimurti Kridalaksana, 1998:2). Dalam kontek budaya, bahasa tidak saja bisa dipandang sebagai sarana komunikasi individu atau kelompok untuk mengungkapkan pikiran, perasaan, pendapat, harapan, kegelisahan, cinta, kebencian, opini, dan sebagainya kepada individu atau kelompok lain, tetapi juga bisa dipan- dang sebagai suatu sumber daya untuk menyingkap misteri budaya, mulai dari prilaku berbahasa, identitas dan kehidupan penutur, pendayagunaan dan pemberdayaan bahasa sampai dengan pengembangan serta pelestarian nilai-nilai budaya. Berangkat dari paradigma ini maka studi tentang bahasa tidak hanya terbatas pada penelitian mikro yang dilakukan semata-mata untuk kepentingan bahasa itu sendiri.

Masyarakat Bali adalah salah satu dari berbagai kelompok etnis yang hidup di kepulauan Indonesia. Identitas masyarakat Bali secara dominan dibentuk oleh budaya Bali yang bernafaskan agama Hindu. Identitas tersebut ditunjang oleh tiga elemen dasar yakni bahasa Bali, seni dan lembaga tradi- 
sional yang didasarkan atas konfigurasi nilai -nilai utama mencakup nilai agama, solidaritas dan estetika. Kelompok etnis masyarakat Bali dicirikan oleh kesadaran yang kuat akan kesatuan budaya, bahasa (Bahasa Bali) dan agama Hindu. Bahasa Bali adalah instrumen utama orang Bali dalam mengintegrasikan dirinya baik secara internal maupun eksternal sebagai individu yang berfungsi dan partisipan aktif dalam kelompok atau masyarakat Bali. Bahasa Bali merupakan bahasa ibu bagi masyarakat Bali dan berfungsi sebagai bahasa komunikasi antar masyarakat Bali. Di samping sebagai media komunikasi, bahasa Bali juga mempunyai fungsi yang penting sebagai bahasa pengantar dari segala aspek kebudayaan Bali yang sangat komplek. Seni merupakan bagian yang tidak terpisahkan dari budaya Bali dan Bali sangat kaya dengan berbagai macam seni termasuk seni rupa, pertunjukan dan sastra. Bagi masyarakat Bali seni sastra merupakan warisan budaya yang agung serta merupakan acuan dan sumber berbagai macam seni lain dan nilai-nilai budaya masyarakatnya.

Masyarakat Bali juga memiliki tradisi lisan dan tulisan (dalam media daun lontar) yang ditunjang oleh sistem aksaranya tersendiri. Satua dan mesatua merupakan tradisi lisan yang masih hidup sampai saat ini. Kebiasaan mesatua merupakan tradisi yang biasanya dilakukan oleh para orang tua (kakek/nenek) pada anak-anak atau cucu mereka sebelum tidur. Terdapat banyak sekali satua yang tersebar di seluruh Bali di delapan kabupaten dan satu kota madya sekalipun sampai saat ini belum terdapat data yang pasti mengenai jumlah satua di Bali. Namun demikian sebagaimana halnya dengan cerita rakyat dari daerah-daerah lain, satua Bali dapat dikelompokkan ke dalam fable, legenda, dan mite. Keanekaragaman isi dalam cerita nampak dalam kisah dan karakter yang dimiliki masing-masing jenis satua.

Mesatua merupakan tradisi yang diturunkan dan dilestarikan dari generasi ke generasi secara oral dan alami di lingkungan keluarga (kebanyakan bukan di kalangan masyarakat perkotaan di mana pengaruh media cetak dan elektronik lebih dominan). Di samping itu pelestarian satua dan mesatua dalam masyarakat Bali juga dilakukan melalui tradisi menulis lontar dengan aksara Bali. Berbagai jenis satua terekam dalam daun lontar dan bisa dijumpai dalam perpustakaan lontar Fakultas Sastra dan Budaya Universitas Udayana dan Gedong Kirtya Singaraja serta koleksi keluarga dan perorangan. Namun demikian kajian berdasarkan suatu pendekatan linguistik modern terhadap teks-teks tradisional seperti satua yang terekam dalam daun lontar tersebut sangat kurang. Kajian yang selama ini dilakukan lebih banyak ter- 
fokus pada pendekatan filologis dan sastra.

Dengan demikian kajian teks menggunakan perspektif linguistik atau sosiolinguistik memberikan alaternatif bagi diversifikasi kajian wacana.

I Juragan Anom adalah sebuah teks tradisional Bali berwujud prosa yang tersimpan di Gedong Kirtya Singaraja dengan Kode Naskah: 2188 VIb. I Juragan Anom tidak saja bisa dipahami sebagai suatu cerita rakyat yang bercerita tentang perjalanan hidup karakter di dalam cerita tersebut yang dikemas dalam struktur kisahan cerita Panji serta memiliki bobot edukatif bagi pendidikan dan pembinaan anak-anak, I Juragan Anom sebagai suatu teks juga mengejawantahkan suatu wacana kebudayaan, stilistik tuturan (communicative style), serta nilai-nilai budaya yang sangat menarik untuk diteliti yang nantinya bisa mengungkap lebih dalam fenomena kebahasaan dan kebudayaan sehingga apresiasi kita terhadap bahasa dan budaya Bali semakin baik

Secara khusus tulisan ini ditujukan untuk memberikan tinjauan teoretis mengenai konsep konteks situasi dan aplikasi model teoretis Hallday tentang konteks situasi terhadap teks I Juragan Anom. Jangkauan pembicaraan dan kajian terhadap teks I Juragan Anom terbatas pada (1) kesatuan teks yang mencakup kesatuan struktur dan texture, (2) konteks situasi dan (3) konteks budaya Ijuragan A nom.

\section{KONSEP DAN KERANGKA TEORI KONSEP \\ KONSEP TEKS}

Teks pada dasarnya adalah suatu produk penggunaan bahasa yang berdasarkan fungsinya dapat dipahami sama seperti bahasa itu sendiri yakni sebagai sarana untuk menyampaikan pesan yang dimiliki oleh penulis kepada pembacanya. Teks mengacu pada bahasa dalam penggunaan. Menurut Halliday (1985:10) teks adalah 'language that is functional'. Istilah functional dalam hal ini menunjukkan pengertian teks sebagai bahasa yang melakukan fungsi dalam konteks tertentu dibedakan dengan kata-kata atau kalimat yang terpisah yang biasa kita lihat ketika guru menuliskan kata-kata atau kalimat di papan tulis atau seperti kalimat yang dijumpai dalam buku tatabahasa ataupun kata-kata yang terdaftar dalam kamus. Suatu teks (baik yang tradisional maupun modern) memiliki bentuk (form) dan isi (subject matter). Secara sederhana bentuk dapat diartikan sebagai struktur yang membangun teks tersebut sedangkan isi merupakan substansi yang dibicarakan dalam teks. Berangkat dari dasar pemikiran di atas maka teks sebagai produk penggunaan bahasa yang memiliki berbagai genre (termasuk teks tradisional seperti naskah tradisional yakni cerita rakyat) memberikan berbagai alternatif kajian yang bersifat linguistik dan 
sosiolinguistik pada khususnya.

\section{KONSEP KAJIAN TEKSTUAL}

Rentangan pengertian studi teks berkisar dari studi teks disiplin ilmu-ilmu kemanusiaan tertentu atau studi pustaka sampai ke studi tentang karya sastra. Studi teks mencakup: (1) studi pustaka sebagai telaah teoritik suatu disiplin ilmu yang perlu dilanjutkan dengan uji empirik untuk memperoleh bukti kebenaran empirik, (2) studi teks yang berupaya mempelajari teori linguistik atau studi kebahasaan atau studi perkembangan bahasa yang biasa disebut studi sosiolinguistik dan psikolinguistik, (3) studi pustaka yang seluruh substansinya memerlukan olahan filosofi atau teoritik dan terkait pada nilai (values), dan (4) studi karya sastra (Muhadjir,1998:159).

\section{KERANGKA TEORI}

Dikaitkan dengan alternatif konsep tersebut di atas studi teks yang dilakukan di sini termasuk studi pustaka sebagai telaah teoritik suatu disiplin ilmu dan mempelajari teori linguistik atau studi kebahasaan dalam teks. Pendekatan yang digunakan dalam kajian terhadap teks tradisional I Juragan Anom bertumpu pada pendekatan socialfunctional Halliday.

Menurut Halliday (1975) teks adalah unit semantik yang direalisasikan dalam unit leksikogramatikal dan selanjutnya diaktualisasikan sebagai unit fonologis atau ortografis. Lebih lanjut dikatakan bahwa teks harus didefinisikan melalui tingkat abstraksi (level of abstraction) bukan ukuran (size) atau dengan kata lain "text is to semantics what sentence is to grammar". Sebuah kalimat harus didefinisikan sebagai " $a$ fundamental unit of grammar" bukan sejenis superphoneme. Begitu juga halnya dengan teks yang harus didefinisikan sebagai "fundamental unit of semantics", bukan sebagai supersentence. Teks sebagai unit semantik dibentuk dengan makna-makna wa-

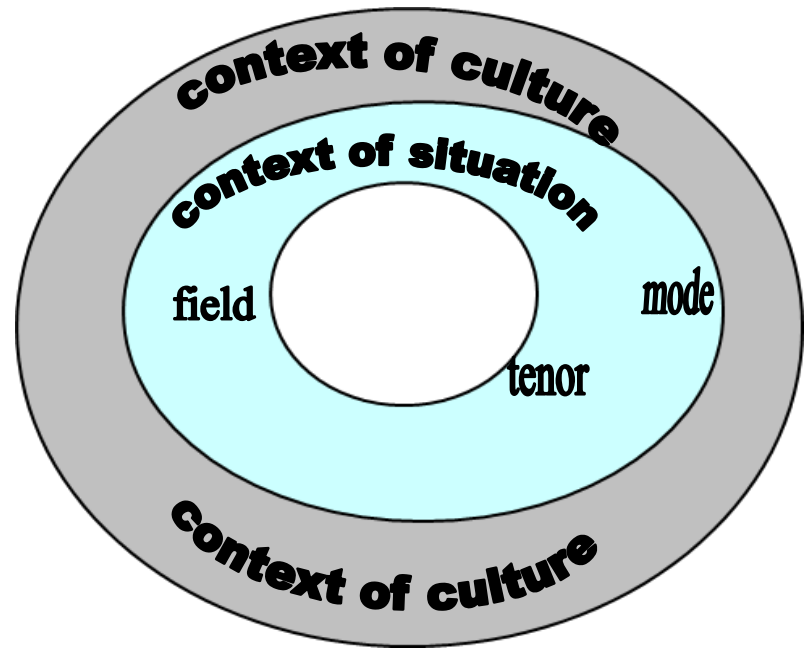

(diadaptasi dari kuliah Wacana oleh Prof Dr. I Gst. Md. Sutjaja, MA,)

Gambar 1. Model Totalitas Makna Sebuah Teks 
Bahasa sebagai fakta sosial selanjutnya juga dianut oleh Halliday (1978) dalam mengembangkan teori teks dan context of situation dan memandang bahasa sebagai semiotik sosial dalam memberikan interpretasi terhadap bahasa dan makna. Berdasarkan praanggapan ini Halliday menawarkan berbagai paradigma studi bahasa. Berangkat dari berbagai sudut pandang terhadap bahasa Halliday mengelompokkan kajian bahasa ke dalam dua jenis yakni (1) yang berasal dari intra-organism perspectives dan (2) inter-organism perspectives yang saling melengkapi. Intra-organism perspectives memandang bahasa sebagai sistem dan telah melahirkan linguistik mikro sedangkan inter-organism perspectives memandang bahasa sebagai behaviour, knowledge, dan art dalam interaksinya dengan bidang pengetahuan lain. Sebagai behaviour bidang ini berinteraksi dengan sosiologi dan melahirkan sosiolinguistik, sebagai knowledge bersentuhan dengan psikologi memunculkan psikolinguistik dan sebagai art kajian bahasa terrealisasi dalam kajian-kajian sastra (Halliday, 1978:9-16)

Ketika memperkenalkan konsep social-funcional approach to language bukanlah berarti Halliday lebih menekankan instrumentality of linguistics daripada autonomy of linguistics. Kuncinya adalah kita harus bisa mengenali berbagai tujuan studi bahasa. Autonomous linguistics merupakan studi bahasa untuk kepentingan memahami sistem linguistik sedangkan instrumental linguistics adalah studi bahasa untuk memahami hal-hal di luar sistem bahasa seperti misalnya sistem sosial. Menurut Halliday, kedua perspektif ini saling melengkapi dan untuk memahami hakekat bahasa itu sendiri kita harus menyatukan kedua perspektif tersebut dan mendekatinya secara fungsional.

Dalam pengertiannya yang paling sederhana kata "fungsi" (function) dapat dipandang sebagai sinonim dari kata "penggunaan" (use). Dengan demikian fungsi bahasa bisa dikatakan sebagai cara bagaimana orang menggunakan bahasanya. Dengan pengertian yang paling umum orang melakukan berbagai hal menggunakan bahasa atau dengan kata lain melalui berbicara dan menulis, dengan menyimak dan membaca orang berharap mencapai berbagai sasaran dan tujuan. Tanpa memperhatikan perbedaan pisik dan lingkungan material, terdapat fungsi bahasa yang amat umum dalam semua kebudayaan manusia: (1) bahasa harus mampu menginterpretasikan keseluruhan pengalaman manusia, (2) bahasa harus mampu mengekspresikan hubungan-hubungan logika dasar tertentu serta yang diciptakan oleh bahasa itu sendiri, (3) bahasa harus mampu mengekspresikan partisipasi seseorang sebagai pembicara dalam situasi wicara, peran yang dimiliki serta peran yang diberikan pada orang lain (lawan 
wicara), keinginan, perasaan, sikap dan penilaian, dan (4) bahasa harus melakukan semua itu secara bersamaan atau dengan kata lain harus mampu disusun sebagai wacana relevan, tidak saja sebagai kata dan kalimat yang terdapat dalam buku tata bahasa dan kamus.

Terdapat sejumlah pakar yang telah mengemukakan pengelompokan fungsi bahasa. Malinowski (1923) mengelompokkan fungsi bahasa ke dalam dua katagori yang luas yakni (1) pragmatik dan (2) magical. Sebagai seorang antropolog dia tertarik dengan pengggunaan praktis atau pragmatik dari bahasa dan penggunaan ritual atau magical yang berhubungan dengan kegiatan upacara atau keagamaan dalam suatu budaya. Pengelompokan lain juga dibuat oleh Karl Buhler (1934) seorang psikolog dari Austria yang memandang fungsi bahasa dari sudut pandang individu bukan budaya dan mengelompokkan fungsi bahasa ke dalam: (1) expressive language yang berorientasi pada self, yakni pembicara, (2) conative language yang berorientasi pada pendengar (addressee), dan (3) representational language yang berorientasi pada realitas yang lain selain pembicara atau addressee. Briton (1970) membuat klasifikasi fungsi bahasa berdasarkan perhatiannya terhadap perkembangan kemampuan menulis anak di sekolah yakni (1) transactional, (2) expressive, dan (3) poetic. Morris (1967) menge- lompokkan fungsi bahasa dari sudut pandang animal behaviorist ke dalam (1) information talking, (2) mood talking, (3) grooming talking, dan (4) exploratory talking. Dari kesemua pengelompokan fungsi bahasa di atas dapat disimpulkan bahwa dalam pengertian fungsi identik dengan penggunaan terdapat 3 jenis fungsi bahasa: (1) informative use yang beorientasi pada isi, (2) interactive use yang berorientasi pada efek, dan (3) imaginative use atau aesthetic use.

Halliday lebih dari sekedar menyamakan fungsi dengan penggunanan yakni menginterpretasikan variasi fungsional tidak saja sebagai variasi dalam penggunaan bahasa tetapi sebagai sesuatu yang terkandung di dalamnya (built in), yakni sebagai satu-satunya dasar bagi pengorganisasian bahasa itu sendiri, dan khususnya bagi pengorganisasian sistem semantik. Fungsi diartikan tidak saja sebagai penggunaan bahasa tetapi sebagai fundamental property of language itu sendiri yakni sesuatu yang amat mendasar bagi evolusi sistem semantik. Haliday menjelaskan teori fungsional bahasa melalui analisis suatu kalimat sebagai representasi penomena dalam dunia nyata yang dipandang memiliki berbagai dimensi makna: (1) experiential meaning yakni makna sebagai ekspresi suatu proses, kejadian, tindakan, keadaan atau aspek penomena dunia nyata lainnya yang 
memiliki hubungan simbolik (bahasa dilihat sebagai reflection), (2) interpersonal meaning di mana bahasa dilihat sebagai action dan dari sudut proses interaksi sosial bukan sebagai cara berfikir tetapi cara berbuat (interaksi antara speaker dan addressee), (3) logical meaning dalam pengertian bukan hubungan logika formal tetapi hubungan darimana logika formal tersebut berasal yang diekspresikan dalam grammar sebagai bentuk lain dari parataksis dan hipotaksis termasuk hubungan koordinasi, aposisi, pengandaian dan kalimat tidak langsung, dan (4) textual meaning yakni apa yang membuat sesuatu menjadi sebuah teks berbeda dengan contoh kata buatan (berkenaan dengan fungsi bahasa dalam membentuk teks, menghubungkan dirinya dengan konteks yakni situasi dan teks sebelumnya).

Fungsi ideational Halliday sepadan dengan fungsi representational Buhler dan fungsi interpersonal Halliday sedikit banyak berpadanan dengan fungsi conative dan expressive Buhler. Fungsi bahasa yang tidak dijumpai dalam pengelompokan pakarpakar lainnya adalah fungsi textual Halliday yakni fungsi yang dimiliki oleh bahasa untuk menciptakan teks, menghubungkan dirinya dengan konteks termasuk siatuasi teks sebelumnya. Fungsi ini dirancang untuk menjelaskan hakekat internal bahasa untuk menghubungkannya dengan lingkungan eksternal bahasa. Kenyataannya setiap kalimat adalah multifungsi. Makna terakit sedemikian rupa sehingga tidak bisa dilihat secara terpisah dari bagian-bagiannya tersendiri tetapi secara bersamaan dari berbagai sudut pandang dan masing-masing perspektif memberi kontribusi pada interpretasi secara keseluruhan. Pandangan ini merupakan hakekat esensial dari pendekatan fungsional.

\section{PEMAHAMAN TENTANG KONTEKS SITUASI}

Konteks mengacu pada hubungan antara bentuk (form) dengan fitur-fitur non linguistik dari situasi di mana bahasa digunakan. Istilah konteks situasi (context of situation) pertama diciptakan oleh Bronislaw Malinowski (1923), seorang antropolog yang penelitiannya banyak sekali dilakukan di wilayah gugusan pulau Pasifik Selatan yakni kepulauan Trobriand (lihat Halliday, 1985:5-6). Di samping context of situation Malionowski juga menciptakan istilah yang ke dua yakni context of culture. Kedua konteks ini dipandang penting untuk bisa memahami teks secara lebih memadai. Walaupun Malinowski pada awalnya menyatakan bahwa konsep konteks situasi ini hanya diperlukan bagi pengkajian bahasa -bahasa 'primitif' tetapi kemudian (1935) dia menyadari bahwa pernyataan itu salah dan yakin bahwa konsep tersebut berlaku bagi semua bahasa baik bahasa orang prim- 
itif atau bahasa dari budaya tak tertulis maupun bahasa modern.

Istilah konteks situasi yang dipelopori oleh Malimowski telah menarik perhatian para linguis seperti J. R. Firth dalam memahami latar belakang budaya bahasa yang selanjutnya mengintegrasikan konsep tersebut dalam teori linguistik.

\section{KONSEP HALLIDAY TENTANG KONTEKS SITUASI}

Halliday (1985:9-10) meyakini bahwa terdapat prinsip-prinsip tertentu yang bisa digunakan untuk memilih cara yang memadai untuk mendeskripsikan konteks situasi. Prinsip sederhana yang memungkinkan berhasilnya suatu komunikasi adalah berupa kemampuan kita untuk mengetahui apa yang akan dikatakan seseorang. Kita membuat perediksi secara tidak sadar dan prosesnya secara umum di bawah tingkat kesadaran. Prediksi ini bisa dimungkinkan melalui konteks situasi. Pada bagian lain Halliday (1985:45) menyatakan bahwa semua penggunaan bahasa memiliki suatu konteks, Ciri-ciri tekstual memungkinkan siatuasi wacana menjadi koheren tidak saja dengan dirinya sendiri tetapi juga dengan konteks situasinya. Teks merupakan suatu contoh proses dan produk dari makna sosial dalam konteks situasi tertentu dan konteks situasi terbungkus dalam teks melalui hubungan sistematik antara lingkungan sosial di satu pihak dan pengorganisasian fungsi bahasa di pihak lain. Konsep konteks situasi Halliday mencakup tiga aspek: bidang wacana (field of discourse) yang mengacu pada (a) apa yang terjadi, (b) hakekat tindak sosial yang terjadi, (c) hal-hal yang melibatkan partisipan dan menempatkan bahasa menjadi bagian penting di dalamnya, tenor wacana yang mengacu siapa yang terlibat yakni partisipan, status dan perannya termasuk jenis hubungan peran yang dimiliki satu sama lainnya baik yang bersifat permanen atau temporer, dan mode of discourse yang mengacu pada peran yang dimainkan oleh bahasa yakni apa yang diharapkan oleh pelibat dari penggunaan bahasa pada situasi tertentu.

Konsep Halliday tentang konteks situasi tersebut di atas merupakan penjabaran teoritis linguistik terhadap konsep konteks situasi dari Malinowski karena terminalnya adalah pemahaman tentang makna teks.. Konsep Halliday dan Firth tentang konteks situasi memiliki kemiripan dalam fokus kajian yakni keduanya efektif dalam analisis suatu genre wacana tertentu. Yang membedakan adalah model Firth lebih condong pada kajian komunikasi verbal atau lisan sedangkan model Halliday lebih bagus diterapkan pada analisis tekstual karena diyakini bahwa prediksi-prediksi mengenai konteks situasi tersurat atau tersirat dalam struktur teks yang dikaji. 


\section{PEMBAHASAN}

\section{STRUKTUR I JURAGAN ANOM}

Teks sebagai produk merupakan suatu keluaran (output) yakni sesuatu yang dapat dicatat dan dipelajari dan memiliki konstruksi yang dapat direpresentasikan secara sistematis. Kesatuan teks dibentuk oleh 2 komponen yakni kesatuan struktur (unity of structure) dan kesatuan texture. Struktur teks dibangun oleh 3 elemen yakni (1) the precipitative event yang berupa kejadian (rangakaian kejadian) yang mendorong alur teks dari satu tahap ke tahap yang berikutnya sehingga akhirnya sampai pada elemen ke dua, (2) the consequential event berupa kejadian-kejadian yang muncul sebagai konsekuensi precipitative event, dan (3) the revelation berwujud kejadian yang mengarah pada pengungkapan faktafakta yang tersembunyi. Revelation merupakan reinterpretasi dari precipitative event (Halliday dan Hasan, 1985: 52)

I Juragan Anom tersusun dalam rangkaian kejadian (sequence of events) berdasarkan sebab akibat. Dalam satua ini, karena Prabu Daha yang telah beristri dan memiliki dua orang anak memperistri I Liku adik dari patih kerajaan Daha (sebagai precipitative event) telah mengakibatkan permaisuri dan putrinya (Raden Galuh) diterlantarkan dan diasingkan ke tengah hutan belantara tanpa pengawal dan bekal serta putranya dijual oleh patih kepada seorang juragan perahu (saudagar) dan selanjutnya dijadikan anak yang diberi nama I Juragan Anom (sebagai consequential event). Ratap tangis permaisuri dan rasa cintanya yang tulus terhadap putrinya di tengah hutan (sebagai precipative event) telah mengundang belas kasihan batara Guru yang selanjutnya mengutus tiga orang bidadari untuk membawakan makanan dan keperluan permasuri Daha dan putrinya tersebut serta mengasuh Raden Galuh dari pagi hingga sore setiap harinya sampai Raden Galuh tumbuh menjadi gadis dewasa (sebagai consequential event). Melalui berjualan berbagai hasil bunga yang ditanam pada taman yang dibuatnya bersama bidadari di hutan ke pasar Kahuripan (sebagai precipitative event), Raden Galuh bertemu dengan Putra mahkota Kahuripan (Raden Mantri Kahuripan) yang selanjutnya sangat mengagumi kecantikan Raden Galuh dan jatuh cinta padanya (sebagai consequential event).

Pada kesempatan lain I Juragan Anom yang menggantikan usaha ayahnya menjadi saudagar berlayar dan berjualan jauh sampai ke Kahuripan (sebagai precipitative event) telah mempertemukan dirinya dengan Raden Mantri Kahuripan yang selanjutnya mengangkat dia sebagai abdi sekaligus teman dan mengajak tinggal di istana (sebagai consequential event). Prabu 
Kahuripan (ayah Raden Mantri) sakit keras dan diramal bahwa beliau hanya bisa disembuhkan dengan daging burung "manuk dewata". Raden Mantri menugaskan I Juragan Anom untuk pergi kemana saja mencari ' 'manuk dewata' dan dilarang kembali sebelum memperoleh burung obat tersebut. Perburuan dan pengembaraan I Juragan Anom mencari "manuk dewata" sampai ke tengah hutan (sebagai precipitative event) mempertemukan dirinya dengan permaisuri Daha dan Raden Galuh (sebagai consequential event). Pengungkapan identitas sebenarnya dari permaisuri Daha dan Raden Galuh kepada I Juragan Anom (sebagai precipitative event sekaligus sebagai revelation) diikuti juga oleh pengungkapan identitas diri I Juragan Anom (bahwa sebenarnya dirinya adalah putra mahkota Daha yang ketika masih kecil dijual kepada juragan perahu oleh patih Daha dan saat itu menjadi abdi Raden Mantri Kahuripan) mempersatukan keluarga kerajaan Daha yang telah lama terpisah tersebut kembali dan membawa suasana bahagia pada mereka merupakan consequential event dan sekaligus revelation dalam satua I Juragan Anom. Kepergian I Juragan Anom yang terlalu sering untuk mengunjungi ibu suri dan adiknya ke tengah hutan (sebagai precipitative event) telah mengundang rasa ingin tahu Raden Mantri Kauripan untuk mengikuti jejaknya dan mengetahui apa sebenarnya yang diper- buatnya selama bepergian (sebagai consequential event).

Pengintaian dan mengikuti jejak I Juragan Anom sampai ke hutan (sebagai precipitative event) telah mempertemukan Raden Mantri Kauripan dengan Raden Galuh, pedagang bunga tercinta yang menghilang dahulu (sebagai consequential event). Pengungkapan identitas I Juragan Anom, Raden Galuh dan dirinya sebagai keluarga kerajaan Daha oleh permaisuri kepada Raden Mantri pada saat dia ingin membunuh I Juragan Anom (sebagai revelation sekaligus precipitative event) telah membuat penyesalan diri Raden Mantri Kahuripan dan meminta maaf kepada mereka dan membawa keluarga kerajaan Daha tersebut ke Kahuripan menemui orang tuanya. (sebagai consequential event dan sekaligus revelation). Akhirnya, pertemuan dan bersatunya kembali keluarga kerajaan Daha, dibunuhnya Ni Limbur serta langgengnya kembali hubungan Daha dan Kauripan melalui pernikahan Raden Galuh Daha dan Raden Mantri Kauripan yang bahagia merupakan revelation dan reinterpretasi precitative event pertama dari kisah tradisional Panji.

DESKRIPSI SITUASIONAL I JURAGAN ANOM

Berdasarkan konsep Halliday (1985) tentang konteks situasi, teks I Juragan Anom memiliki tiga komponen wacana: (1) 
field of discourse, (2) tenor of discourse, dan (3) mode of discourse.

\section{(1) Field of discourse dari I Juragan Anom}

I Juragan Anom adalah sebuah cerita rakyat (folk tale) Bali yakni dongeng anak sebelum tidur berbentuk prosa naratif. Struktur alur cerita tersebut mengikuti versi cerita Panji. Tema cerita mengajarkan anakanak akan kebajikan dan karma phala. Sampai batas-batas tertentu pola alur cerita $I J u$ ragan Anom identik dengan pola alur universal dari the Hero of Tradition yang dirumuskan oleh Lord Raglan (1965:145) berdasarkan studi mendalam tentang foklor. Kemiripan tersebut tercermin dalam: orang tua I Juragan Anom adalah raja dan permaisuri (Kerajaan Daha) oleh karena sesuatu hal, sejak kecil ia dipisahkan dengan orang tuanya, I Juragan Anom diangkat menjadi anak dan dibesarkan oleh orang lain, Tidak begitu banyak diceritakan tentang masa kecilnya tetapi ketika menjelang dewasa dia berkelana menjalani berbagai tantangan sampai akhirnya dipertemukan dengan keluarganya, Pertemuan keluarga kerajaan tersebut berakhir dengan kebahagiaan dan selanjutnya mewarisi tahta kerajaan. Prinsip sederhana yang memungkinkan berhasilnya suatu komunikasi adalah berupa kemampuan kita untuk mengetahui apa yang akan dikatakan seseorang. Kita membuat perediksi secara tidak sadar dan prosesnya secara umum di bawah tingkat kesadaran. Partisipan dalam suatu budaya memanfaatkan hubungan yang erat antara teks dengan situasi sebagai dasar interaksinya. Kita dapat dan harus membuat kesimpulan (inferences) dari situasi terhadap teks, tentang jenis-jenis makna yang disampaikan begitu pula sebaliknya mengadakan inference dari teks terhadap situasi. Namun demikian kadang kala kita harus melakukan inference hanya dalam satu arah. Contohnya yang paling jelas adalah teks sastra seperti I Juragan Anom. Tidak ada situasi lain kecuali situasi eksternal sebagai pembaca dan harus membangun situasi internal dari membaca teks tersebut.

Sebagai pembaca, kita bisa mengambil kesimpulan tentang konteks situasi dari teks I Juragan Anom. Ketika membaca kalimat pertama dari teks I Juragan Anom yang berbunyi "Ada kone tuturtuturan satua, I Juragan Anom.," kita seketika mengetahui bahwa kita sedang diceritakan cerita tradisional (cerita anak) karena tak ada situasi lain selain cerita anak yang memakai ekspresi tersebut. Selanjutnya kita bisa memprediksi apa yang akan terjadi selanjutnya seperti misalnya teks tersebut akan dibacakan atau diceritakan kembali (mesatua) kepada anak kecil. Dalam proses pengisahan selanjutnya bisa diprediksi akan adanya ekspresi yang menunjukkan urutan kejadian, transisi dan pengalihan fokus kisahan seperti dalam ungkapan- 
ungkapan berikut: lantas; $\underline{\text { kone; }}$ kasuensuen; Kacarita Ida Sri Pramesuari peteng lemah kone ida sedih di tengah alase; Kasuen-suen gelisang satua ...; Kacaritanan gelisan satua...; Tan caritanan gelisang satua ...; Tan caritanan Ida Raden Mantri, kacarita jani (I Juragan Anom...

Fitur-fitur semantik yang bisa dijelaskan dengan mengacu fitur situasi field of discourse tersebut di atas merupakan aspek pola transitivitas. Sebagaimana yang dirangkum oleh Sutjaja (1996) melalui berbagai rujukan, sistem transitivitas mengacu pada "siapa melakukan sesuatu kepada siapa/si(apa) adalah (si)apa, kapan, di mana, mengapa atau bagaimana berfungsi" Ada tiga katagori semantik yang secara umum menjelaskan keadaan atau fenomena dunia yang diwujudkan sebagai struktur kebahasaan yakni (1) sirkumstans, (2) proses, dan (3) partisipan.

Dalam teks I Juragan Anom ketiga kategori semantik tersebut di atas tercermin. Kategori sirkumstans yang mengacu pada (a) waktu (temporal) yang menyatakan $k a$ pan, seberapa sering dan berapa lama terealisasi dalam teks melalui penggunaan katakata seperti: sekat ento, peteng lemah, saisai, semengan gati, mani puan, (b) tempat (spatial) yang menyatakan lokasi seperti $d i$ alase wayah, ke suargan, di bancingah, di bale bengonge, ke perahune, (c) cara yang menyatakan kualitas bagaimana seperti alase wayah, dan gati, (d) sebab yang menyatakan alasan atau mengapa seperti kata reh (sewireh) dan tujuan (untuk apa?) seperti dalam melayar, madadagangan dan kautus, maktaang, dan (e) penyertaan yang dinyatakan lewat dengan siapa seperti dalam ungkapan lunga kairing baan Punta, dan miwah.

Berbagai katagori proses tercermin dalam teks I Juragan A nom seperti: (a) proses material yang terealisasi dalam teks melalui kata-kata: ngadep, kakutang, kekaryanang, melayar, (b) proses prilaku yang terealisasi melalui kata-kata seperti ngambil, maktaang, dan medagangan, (c) proses mental yang terealisasi melalui kata-kata seperti sedih, buduh, osek, sungkan, bendu, dan makeneh, (d) proses verbal yang terealisasi melalui penggunaan kata-kata ngandika, matur, kaukin, midartayang, dan nguningayang, (e) proses relasional yang terealisasi melalui kata-kata seperti madue, kari alit-alit, kaadanin, dan "titiang jadma pangumbara", dan (f) proses eksistensial seperti kata yang terealisasi melalui kata $a d a$.

\section{(2) Tenor of discourse dari I Juragan} Anom

Tenor mengacu pada hubungan personal yang terlibat termasuk antara pembicara dengan pendengar dalam komunikasi lisan dan antara penulis/ narrator dengan pembaca. dan keseluruhan hubungan yang 


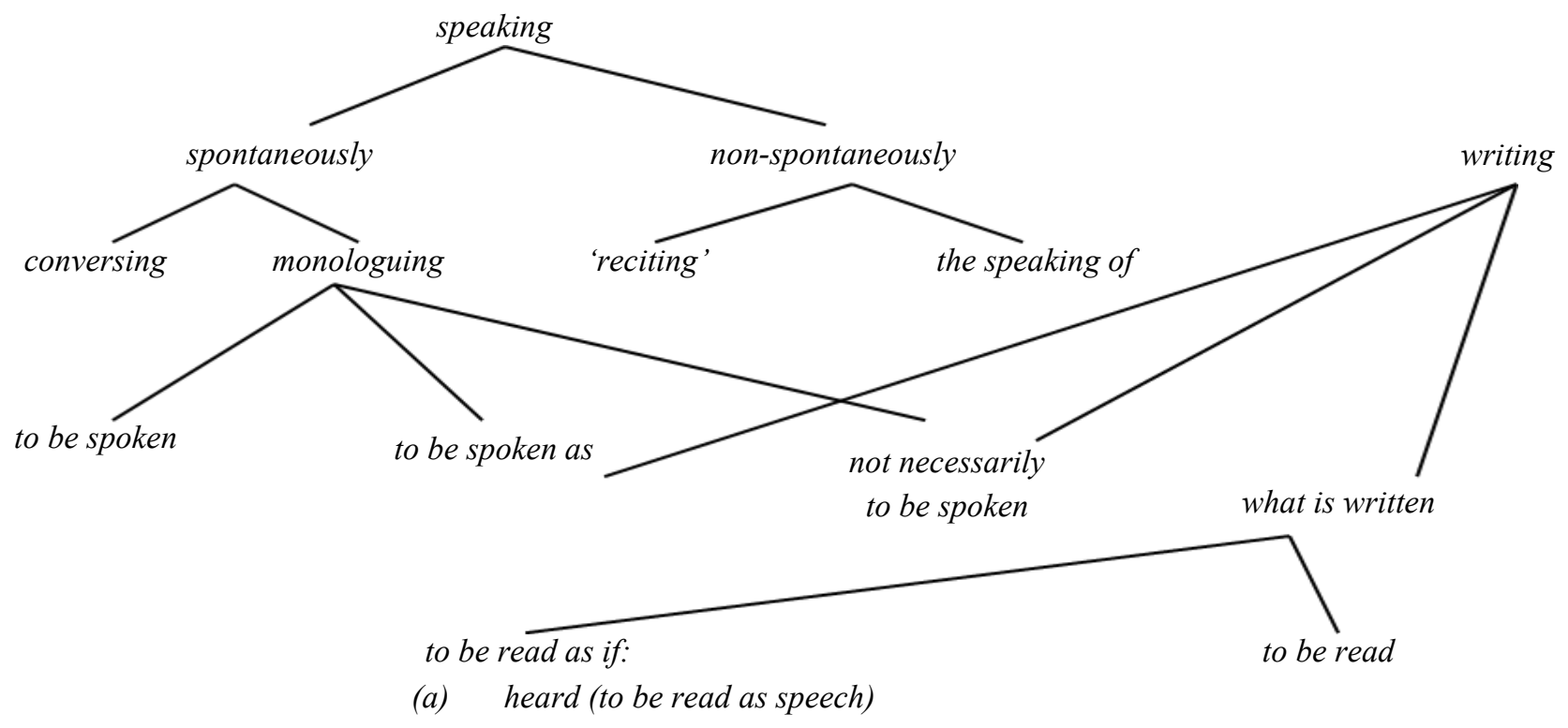

Berdasarkan diagram tersebut di atas dapat disimpulkan bahwa I Juragan Anom adalah teks tulis yang harus diucapkan atau diceriterakan secara oral seolah-olah tidak tertulis.

\section{KONTEKS BUDAYA I JURAGAN ANOM}

Masyarakat Bali memiliki tradisi lisan dan tulis yang didukung oleh sistem aksaranya sendiri. I Juragan Anom adalah sebuah teks tradisional yang termasuk dalam genre cerita rakyat (folktale) yang dalam bahasa Bali dikenal dengan satua. Mesatua (story telling) merupakan tradisi oral di Bali yang masih hidup sampai dewasa ini. Kegiatan mesatua merupakan tradisi yang biasanya dilakukan oleh para orang tua (kakek/nenek) pada anak-anak atau cucu mereka sebelum tidur. Satua berasal dari cerita lisan yang berhubungan erat sekali dengan dunia anak. Dalam perkembangannya tradisi sastra ini terletak pada aspek kelisanannya. Aspek ini mengandung pengertian bahwa aktualisasi komunikasi mesatua memerlukan kehadiran pendengar (khususnya anak-anak atau anggota keluatga yang lainnya) dan seorang pendongeng atau tukang satua (bisa seorang ayah, ibu, nenek atau kakek dalam keluarga).

Mesatua dicirikan oleh ekspresi lisan sehingga memiliki gayanya tersendiri sesuai dengan si pencerita. Ciri yang paling jelas bisa ditandai dalam kegiatan mesatua adalah kehadiran dialog antara si pencerita (story teller) dengan pendengar (audience). Dialog tersebut biasanya terjadi pada saat memulai mesatua dan sering diulang-ulang pada tengah cerita:

$$
\begin{aligned}
& \text { Si Pencerita : Ada kone tutur-tuturan } \\
& \text { satua, I Juragan Anom, "maan dong keto" } \\
& \text { 'Konon ada sebuah cerita, I }
\end{aligned}
$$


Juragan Anom. Dengarkanlah’

Si Pendengar :"Maan" (respon menandakan si pendengar sedang mendengarkan si pencerita dan pada pertengahan $m e$ satua berarti 'lanjutkan')

Dialog tersebut dimaksudkan untuk mengarahkan perhatian pendengar untuk mendengarkan cerita yang disampaikan. Ekspresi maan dong keto digunakan mengecek respon pendengar apakah mereka sedang mendengarkan cerita. Dan pendengar akan merespon dengan maan sebagai pertanda mereka sedang mendengarkan. $\mathrm{Me}$ satua selalu diawali dengan bentuk kalimat pembuka yang baku seperti "Ada kone tutur -tuturan satua" atau variasinya "Ada kone orah-orahan satua".

Kehadiran kata kone berhubungan dengan asal mula dari cerita. Kata ini mengimplikasikan keanoniman sifat penulis cerita tersebut serta mengandung pemahaman bahwa cerita tersebut tidak dikarang oleh pencerita sendiri tetapi berasal dari orang lain. Dengan kata lain kata kone mengisyaratkan bahwa satua tersebut telah dituturkan secara turun temurun. Secara etimologi kata ulang tutur-tuturan dapat dijelaskan berasal dari kata tutur yang bermakna petuah. Makna ini mengkonotasikan bahwa satua tersebut dimaksudkan untuk memberikan petuah-petuah hidup, nilai-nilai moral dan etika kepada pendengarnya. Dan secara idiomatik kata tutur-tuturan atau orah-orahan menyiratkan makna berceritera secara lisan.

Generasi lebih tua memanfaatkan mesatua di dalam keluarga sebagai sarana untuk pembentukan watak bagi anak pada awal-awal pertumbuhan mereka. Melalui kegiatan ini keluarga nampak menempati posisi sebagai institusi pendidikan. Pada saat mesatua para pencerita (orang tua) melakukan improvisasi untuk memperkenalkan pengetahuan-pengetahuan umum tentang alam dan lingkungan di samping nilainilai moral dan etika. Namun demikian tentu saja improvisasi seperti tersebut di atas sangat tergantung pada ketrampilan atau bakat serta wawasan pengetahuan si pencerita. Tetapi inti dari kegiatan mesatua ini adalah kesempatan untuk bisa berkumpul, bersama-sama di dalam keluarga untuk membangun dan mempertahankan hubungan erat antara orang tua dan anak. Pada saat mesatua anak-anak akan berkerumun dekat-dekat orang tua (pencerita). Para orang tua akan bercerita dan membuat atmosfer yang mengesankan bahwa belajar itu sangat menyenangkan. Dari satua yang diceritakan mereka bisa belajar tentang hidup dan kehidupan serta menikmati hiburan berupa cerita tersebut. Selanjutnya anakanak akan menyadari akan nilai-nilai sisioreligius Bali yang tersirat dalam satua atau yang diperkenalkan oleh para orang tua pa- 
da saat mesatua seperti misalnya (1) kepercayaan akan adanya kekuatan di luar kemampuan dan pikiran manusia, (2) cara bertingkah laku dan karma phala, dan (3) aspek-aspek tri hita karana dan sebagainya.

Sayang sekali bahwa terdapat kecenderungan menurunnya intensitas tradisi mesatua. Pada keluarga-keluarga perkotaan kebiasaan bercerita kepada anak menjelang tidur hampir punah. Berdasarkan penelitian yang dilakukan oleh Tim Universitas Udayana tahun 1993 yang disponsori oleh Pemerintah Daerah Bali menunjukkan bahwa dari 50 kecamatan di Bali, 30 kecamatan menunjukkan bahwa kegiatan mesatua sebagai tradisi keluarga jarang sekali dilakukan bahkan pada 2 kecamatan kegiatan mesatua tidak masih ditemukan. Menurunnya kegiatan mesatua disebabkan oleh berbagai faktor seperti pertimbangan praktis, inovasi teknologi,dan perubahan selera masyarakat pendukungnya. Karena merasa kaya dengan satua yang diturunkan dari generasi ke generasi, dari mulut ke mulut, pemikiran untuk menciptakan atau menulis satua baru kurang mendapat perhatian dan tidak ada dorongan yang serius dari institusi terkait untuk penulisan satua baru. Kemajuan teknologi yang menjanjikan tokoh-tokoh elit dan super secara audiovisual telah mengurangi minat atau kurang mendorong para orang tua menciptakan satua baru karena satua-satua yang sudah ada cukup memadai. Bakat dan ketrampilan untuk menghasilkan satua menurun sebagai akibat kurangnya tuntunan dari tokoh-tokoh yang memiliki kemampuan seperti guru, para ahli dan tukang satua yang terampil. Para orang tua cenderung menempatkan kebutuhan ekonomi paling utama sehingga hampir tidak memiliki waktu luang untuk bercerita pada anak menjelang tidur.

Yang paling menyedihkan adalah kenyataan bahwa anak-anak tidak lagi tertarik akan tokoh-tokoh tradisional dalam satua dan menganggap tokoh-tokoh tersebut sulit dimengertikan atau dihubungkan dengan keberadaan mereka saat ini. Di samping itu, anak-anak kurang mengerti akan satua yang diceritakan dalam bahasa Bali karena mereka sebagian besar menggunakan bahasa Indonesia dalam pergaulan sehari-harinya. Sementara itu para orang tua juga cenderung mengesampingkan pentingnya hubungan yang erat antara orang tua dan anak yang bisa dibangun pada saat mesatua. Anak-anak sekolah khususnya lebih suka membaca mendengar atau menonton di TV tokoh-tokoh asing. Mereka lebih tertarik menikmati hiburan yang ditawarkan oleh majalah anak-anak, radio swasta dan khususnya siaran TV yang telah merambah setiap rumah di semua desa di Bali. Sampai batas-batas tertentu media ini telah menggantikan posisi tukang satua di Bali. Dan ironisnya ada anggapan di ka- 
langan generasi baru bahwa mesatua ketinggalan jaman.

Sekalipun masyarakat Bali sepakat terhadap langkanya kegiatan mesatua dewasa ini namun tidaklah berarti bahwa tradisi ini sudah punah. Kenyataannya adalah terdapat pergeseran persepsi pada hakekat mesatua. Selama ini mesatua dipandang sebagai tradisi keluarga yang bersifat spontan dan semua orang tua pada masyarakat Bali adalah pencerita. Dewasa ini mesatua tidak hanya merupakan suatu tradisi keluarga (walaupun tradisi ini merupakan pemandangan yang jarang khususnya di daerah perkotaan) tetapi juga muncul sebagai seni pentas (performing art). Mesatua tidak hanya dilakukan di lingkungan keluarga tetapi telah menjadi tontonan (stage) yang dipertunjukkan di depan umum dan disiarkan melalui radio dan televisi. Dalam perkembangannya dewasa ini bahkan tradisi mesatua tidak hanya dilakukan oleh para orang tua atau kakek/ nenek untuk menidurkan anak tetapi juga oleh anak-anak sekolah walaupun sifatnya insidental melalui kontes di sekolah pada perayaan atau event tertentu yang tentu saja dimaksudkan untuk melatih anak-anak atau siswa untuk berbicara bahasa Bali yang baik dan benar di satu sisi dan lebih mencintai dan melestarikan kebudayaan mereka di sisi lain.

\section{SIMPULAN}

I Juragan Anom adalah sebuah teks tradisional Bali berwujud prosa naratif yang tidak saja bisa dipahami sebagai suatu cerita rakyat yang bercerita tentang perjalanan hidup karakter di dalam cerita tersebut yang dikemas dalam struktur kisahan cerita Panji dan memiliki sejumlah kesamaan struktur alur universal dari the Hero of Tradition serta memiliki bobot edukatif bagi pendidikan dan pembinaan anak-anak. I Juragan Anom sebagai suatu teks juga mengejawantahkan suatu wacana kebudayaan, stilistik tuturan (communicative style), serta nilai-nilai budaya Bali.

Pembaca dapat membuat kesimpulan (inferences) dari situasi terhadap teks, tentang jenis-jenis makna yang disampaikan begitu pula sebaliknya mengadakan inference dari teks terhadap situasi dalam satu arah. Tidak ada situasi lain kecuali situasi eksternal sebagai pembaca dan harus membangun situasi internal dari membaca teks tersebut. Konteks situasi I Juragan Anom memiliki tiga komponen wacana: (1) field of discourse, (2) tenor of discourse, dan (3) mode of discourse

Dalam teks I Juragan Anom ketiga kategori semantik seperti sirkumstans yang mengacu pada (a), proses, (b) tempat (spatial) c) cara, (d) sebab dan (e) penyertaan jelas tercermin. Berbagai katagori proses tercermin dalam teks I Juragan Anom seperti: (a) proses material, (b) pros- 
es prilaku, (c) proses mental, (d) proses verbal, (e) proses relasional dan (f) proses eksistensial.

Komponen partisipan dalam I Juragan Anom mencakup penulis yang anonim dan pembaca yang sangat terbuka, boleh siapa saja yang berasal dari status social yang berbeda dari segi umur, pendidikan, pekerjaan, asal dan sebagainya yang bisa berbahasa Bali dan mampu membaca aksara Bali dalam lontar. Dengan mengidentifikasi I Juragan Anom sebagai satua di mana penulisnya menjadi anonim memungkinkan suatu prediksi bahwa teks tersebut sebagai materi dalam kegiatan mesatua (story telling). Oleh karena itu dalam konteks mesatua partisipan yang terlibat menjadi komunikasi antara narator dan pendengar (biasanya anak-anak) atau suatu pemandangan seorang sedang membacakan cerita kepada anak-anak. I Juragan Anom merupakan teks tulis yang harus diucapkan atau diceriterakan secara oral seolah-olah tidak tertulis

Secara budaya I Juragan Anom adalah sebuah teks tradisional yang termasuk dalam genre cerita rakyat (folktale) yang dalam bahasa Bali dikenal dengan satua sebagai bagian dari kegiatan mesatua (story telling) yang merupakan tradisi oral di Bali yang masih hidup sampai dewasa ini.

\section{UCAPAN TERIMA KASIH}

Penulis menyampaikan rasa terimakasih kepada Prof Dr. I Gusti Made Sutjaja, MA yang telah memperluas wawasan penulis tentang kajian teks dan menghadiahkan buku Terms in Systemic Linguistics: A Guide to Halliday karya Alex De Joia dan Adrian Stenton (1980) yang sangat mempermudah bacaan penulis untuk memahami dan mengaplikasikan konsep dan teori yang dikemukakan oleh Halliday tentang teks dan kajian tekstual.

\section{DAFTAR PUSTAKA}

Bolinger, Dwight. 1975. A spects of Language. USA: Harcourt Brace Jovanovich, Inc.

Brunvand, Jan Harold. 1977. The Study of American Folklore: An Introduction, Second edition. New York: W.W.Norton \& Company, Inc.

De Joia, Alex dan Adrian Stenton. 1980. Terms in Systemic Linguistics: A Guide to Halliday. London: Belling \& Sons Ltd, Guilford and Worcester.

Dundes, Alan. 1965. The Study of Folklore. USA: Prentice Hall, Inc.

Goddard, Cliff dan Anna Wierzbicka. 1996. Discourse and Culture dalam The Third Autralian Linguistic Institute. Australian National University, July 1- 12, 1996. Cross-Cultural Communication.

Halliday, M.A.K. 1978. Language as Social Semiotic: The Social Interpretation of Language and meaning. London: Edward Arnold. ,dan Ruqaiya Hasan.1985. Language, Context, and Text: Aspect of Language in a Social-semiotic Perspective. Victoria: Deakin University Press.

Hatim, B dan I. Mason.1990. Discourse and the Translator.England: Longman Group UK Limited.

Hill, Archibald A (Ed.). 1978. Linguistics. USA: Voice of America Forum Series

Holmes, Janet. 1992. An Introduction to Sociolinguistics. London and New York: Longman.

Hymes, D. H. 1962. The Ethnography of Speak- 